\title{
Pathways and Processes: Reviewing the Role of Young Adults in Urban Structure
}

\author{
Nick Revington \\ School of Planning \\ Faculty of Environment \\ University of Waterloo \\ nwreving@uwaterloo.ca
}

This is an Accepted Manuscript of an article published by Taylor \& Francis in The Professional Geographer on March 31, 2017, available online:

http://www.tandfonline.com/doi/full/10.1080/00330124.2017.1288574

Full citation:

Revington, N. (2018). Pathways and Processes: Reviewing the Role of Young Adults in Urban Structure. The Professional Geographer 70(1), pp. 1-10. 


\begin{abstract}
$\underline{\text { Abstract }}$
Challenges arising from changing demographics, expensive housing and precarious labour have prompted recent interest in the residential geographies of young adults. Yet, despite attention to young adults' diverse housing pathways, I argue that greater focus is needed on the place-based and spatial underpinnings and effects of particular housing pathways: connections to urban processes of "youthification" - the concentration of young adults in dense neighbourhoods - and "studentification" - whereby an area becomes dominated by university students - remain underdeveloped, as do linkages between these phenomena and gentrification. I explore these connections through a critical review of extant literature, to show that the enactment of some pathways is associated with particular urban processes, which may foreclose certain pathways for other individuals. Finally, I identify three crucial areas of inquiry: 1) how youthification, studentification, and gentrification interact; 2) how these processes shape and are shaped by diverging individual housing pathways; and 3) how differences among young adults such as race, ethnicity, and gender intersect with age in the course of these processes.
\end{abstract}

Keywords: gentrification, housing pathways, studentification, young adults, youthification 
In light of demographic changes taking place in North America and Europe, the young adult phase of the life course - that is, the transition between adolescence and adulthood - is often seen as elongated relative to the past. Young adults are, for instance, living in the parental home longer, spending longer times in post-secondary education, and delaying or rejecting marriage and child-bearing (Clark 2007; Côté and Bynner 2008; Furlong and Cartmel 2007). There is correspondingly a trend toward smaller household sizes and an increase in the number of single-person households (Beer et al. 2011; Townshend and Walker 2015). Considerable recent work has drawn attention to the housing challenges particular to young adults. Compared to previous generations, today's young adults face an increasingly expensive housing market in cities in a number of national contexts across the Global North (Demographia 2015). Neoliberal market reforms have directed support away from social housing (Beer et al. 2011; Sager 2011) while facilitating an increasingly flexible, and therefore precarious, labour market (Arnold and Bongiovi 2013; Vosko 2006).

These trends have implications for the urban spatial patterns of young adults, the full breadth of which remain undertheorized. In this review, I interpret these patterns, and their implications for gentrification and related processes of youthification (Moos 2015) and studentification (Smith 2005), through a framework of housing pathways. ${ }^{1}$ Housing pathways are "patterns of interaction (practices) concerning house and home, over time and space" (Clapham 2002, 63), recognizing both the individual meanings and choices associated with housing, and broader structural constraints across the life course, and therefore variegated experiences of housing. The aim is to avoid "the inadequacies of traditional approaches in economics and geography, which assumed universal and simple attitudes and motivations" (Clapham 2002, 63). This represents an improvement on concepts such as housing careers (which assume an upward 
trajectory from a single starting point to a universal goal, downplaying structural influences), housing histories (which focus on structure), and housing biographies (which privilege subjective experience) (Beer et al. 2011). ${ }^{2}$

I adopt this pathways framework to emphasize their place-based and spatial underpinnings and effects. Neighbourhood level processes such as gentrification, youthification, and studentification are bound to shape housing pathways, while simultaneously, the enactment of certain pathways as opposed to others shapes urban processes. At the same time, the individual pathways implicated in neighbourhood changes can offer potential insights into the links between gentrification, youthification, and studentification - illuminating, for example, how and when these processes do or do not interact or overlap.

I focus on the North American and European context, given their preponderance in Anglophone scholarship and relative degree of similarity, although references will be made to other contexts where appropriate. Nonetheless, considerable differences exist between national contexts. For instance, the importance of familism in certain cultures - where high value is placed on the family rather than the individual - means it is more common historically and contemporarily for young adults to live in the parental home for longer than is typical in North America or northern and western Europe, as is the case in southern Europe and some Asian countries (Emmanuel 2013; Li 2013; Poggio 2013; Yip 2013). These differences in norms problematize the notion that the changes taking place in North America and northern Europe are inherently either good or bad. Rather, these changes may represent more of a convergence with much of the rest of the world. However, labour and housing market trends in several countries have placed greater strain on families as a support system for young adults (Emmanuel 2013; Poggio 2013; Sage, Evandrou, and Falkingham 2013), and in some places where cohabitation 
with relatives is common, there is evidence that young adults nonetheless yearn for housing independent of older generations of the family (Zavisca 2013; Yip 2013).

Regardless of cultural norms surrounding young adults' housing, the structural, cultural and demographic changes that have altered the nature of young adulthood - in particular by lengthening it and blurring its edges - are likely to be disruptive in some way, and of disproportionate impact. Indeed, while issues of housing affordability and labour market precariousness are not unique to young adults, this period remains the stage in life when most leave the parental home for the first time and make decisions regarding having children and pursuing homeownership (Öst 2012a), and these remain significant life events. Largely due to post-Fordist and neoliberal economic restructuring, the incomes of young adults have declined relative to both older age groups and young adults in the past (Moos 2014a) while the flexibilization of work reduces eligibility for mortgages, independent of income (Öst 2012b).

Buying into the market has therefore become less attainable to many, and homeownership among young adults is increasingly stratified by income and unstable (Beer et al. 2011; Brown and Lafrance 2013; Öst 2012b). In the most expensive metropolitan areas, those able to buy have generally not benefitted from the price appreciation experienced by existing owners, requiring instead large mortgages that put young households in a position of greater financial vulnerability than others (Walks 2013), for instance in the event of a market crash or job loss. Conversely, government interventions to prevent real estate crashes via a bailout of that sector can represent a redistribution of wealth from non-owners to owners, with young adults over-represented in the former rather than the latter (Walks 2014).

Amidst these demographic and market changes, the housing experiences and geographies of young adults have also evolved. I begin by charting the diverse housing pathways experienced 
by young adults through an overview of recent literature within geography and related fields concerned with the constraints faced by young adults in accessing housing and the strategies used to overcome them. In the subsequent two sections, respectively, I explore the connections between these housing pathways and the changing spatial patterns of young adults generally, and higher education students specifically, bringing these concepts into conversation with each other. In doing so, I critically review the relationship of these trends to gentrification. Finally, I identify some directions for further research before concluding briefly.

\section{Changing Housing Pathways of Young Adults}

As a result of the particular challenges facing them, some have argued that since the 1980s, young adults can be conceived of entering a specific "youth" housing market - rather than simply entering the housing market at large - which is characterized by "shared housing, precarious housing, temporary housing and frequent mobility, and which is clearly distinct from accessing and holding housing in a 'mature' or 'adult' market" (Ford, Rugg, and Burrows 2002, 2456). Consequent to this change, there has been a shift in the housing pathways of young adults since the earlier postwar period.

Based on an extensive set of interviews, Ford, Rugg, and Burrows (2002) identify three factors on which such pathways depend: the ability of young adults to plan and control entry to independent living; constraints such as income, access to welfare benefits, local housing market conditions, and so forth; and the degree of family support. They also identify five ideal-type housing pathways. However, more recent work has uncovered a broader range of pathways through the use of cluster analysis, positing the existence of nine pathways, and estimating the population of each within the UK (Clapham et al. 2014). In a study of Amsterdam, others have identified three primary housing pathways (Hochstenbach and Boterman 2015). Presented in 
Table 1, these pathways should be considered not as immutable categories, but as common outcomes given individuals' resources, constraints, and choices.

\section{[Insert Table 1 about here.]}

This diversity of experience is corroborated by Sage, Evandrou, and Falkingham (2013), who examine, over five years, the migration patterns of former university students in the UK. Reasons for moving were diverse, and not merely for employment. Moreover, nearly half of respondents returned to the parental home during the study period, and doing so remained a common reason to move within the first four moves made by respondents. It would seem, contra Ford, Rugg, and Burrows (2002), that students do not pursue a homogenous pathway. Similarly, chaotic pathways should not necessarily be equated with marginality. While those who are unable to deal with housing constraints may continue to "reproduce" their precarity, alternative housing arrangements (often informal or semi-illegal) and frequent moves can also be a strategy to access housing in ideal neighbourhoods in the absence of adequate economic capital (Hochstenbach and Boterman 2015; see also Mendez 2011).

Despite differences in methodology, geography, timeframe, and the number of pathways identified, some coherent conclusions can be drawn from this ensemble of literature. In particular, it is obvious that the housing experiences of young adults are heterogeneous, often drawing on the "parental safety net" (Sage, Evandrou, and Falkingham 2013) of gifts and loans (Heath and Calvert 2013) and friend networks, through what may be described as social and cultural capital (Hochstenbach and Boterman 2015). There is also an increasing reliance on the private rental sector of the housing market. As young adults spend longer amounts of time in this sector, they increase competition for rental housing, pushing up rents, with negative implications for low income groups (Ford, Rugg, and Burrows 2002). It appears that shifts toward this sector 
are producing a convergence in pathways, whereby renting is more common regardless of substantial differences in the context and conditions of - and reasons for - renting (Clapham et al. 2014).

There is also a spatial dimension to these trends. Yet despite the inclusion of "space" in their definition (Clapham 2002), little attention has been given to how individual pathways are implicated in neighbourhood changes or vice versa. However, housing pathways unfold in particular places, and young adults have distinct urban geographies that are usefully interpreted through a pathways framework.

\section{Changing Geographies of Young Adults}

With changes in young adults' housing pathways, it is imperative to understand broader changes in the geographies of young adults. A burgeoning literature has developed on the geographies of youth, predominantly centred on the everyday spaces of youth as well as contesting the nature of childhood and youth. Much of this has focused on children, or sometimes up to the age of about 25 (although boundaries are, of course, fuzzy - see Valentine 2003 ) rather than young adults more broadly defined (Evans 2008; Hörschelmann and van Blerk 2012; Vanderbeck 2007). Some have observed that among those who do consider young adults, housing is often overlooked relative to employment and education (Arundel and Ronald 2016; Cuervo and Wyn 2014; Hoolachan et al. 2016), although this may be changing. Gorman-Murray (2015), for example, has examined the diverse relationships between gender (specifically, masculinities) and domesticities to demonstrate how these are spatially constructed at home. Beyond attention to the micro-spaces of home, research has also problematized the extent to which economic factors explain young adults' return to rural home regions, arguing for a greater role of sense of home and place (Haartsen and Thissen 2014; Rérat 2014). 
Economic factors, of course, do have some role to play. Hoolachan et al. (2016) found geographical differences in difficulties faced by young adults in the private rental sector in Scotland between urban and rural regions as well as between expensive and less expensive markets. Regional differences in housing systems and welfare regimes also matter (Arundel and Ronald 2016). Some metropolitan areas have higher relative populations of young adults than others: typically, those with strong economic performance and therefore greater opportunity for young adults to begin working careers, although high housing costs in the most "global" of these cities may also be a deterrent. Meanwhile, cities with poorer economic prospects appear less adept at attracting young adults and therefore tend to feature older average populations (Rosenberg and Wilson 2010; Moos 2015).

Patterns of change also exist within cities, and so it is necessary to consider the relationality of these changes to young adults' life course changes (Hall, Coffey and Lashua 2009). In fact, urban change is not entirely external to young adults. Young adults are increasingly found in the denser central neighbourhoods of cities in North America (Moos 2014b; 2015; Generationed City n.d.), the UK (Bromley, Tallon, and Roberts 2007) and continental Europe (Buzar, Hall, and Ogden 2007; Buzar et al. 2007; Kabisch and Haase 2011; van Criekingen 2010), especially those with improved downtown amenities. However, for the most part, young adults have not been the focus of study per se. In an examination of trends in 10 regionally diverse Canadian cities, Meligrana and Skaburskis (2005) found that among factors such as distance to the central business district, income and rent levels, and dwelling characteristics, the presence of young adults was also linked to gentrification. In particular, typical gentrifying households are "young, well-educated, highly mobile and single-person 
households" (1585), with gentrifying census tracts seeing an increase in the proportion of those aged 25-39, from 24 to 32 percent.

Re-urbanization, conceptualized as an increase in the population of the core of an urban agglomeration, also appears to be driven by young adults. In four UK cities, Birmingham, Bristol, Cardiff, and Swansea, policies to repopulate inner cities have resulted in a disproportionate share of young adults and lone-person households within city centres by 2001 (Bromley, Tallon, and Roberts 2007). While increased since 1991, there was already a relatively high proportion of young adults in these areas at that time, and this increase is not entirely the result of increasing numbers of students. Bromley, Tallon, and Roberts $(2007,144)$ further note that these city centres are of "similar, or of higher, social status than the city districts as a whole," and have experienced a "striking" rise in status since 1991. Meanwhile, in Leipzig, Germany; Ljubljana, Slovenia; Bologna, Italy; and Leon, Spain, re-urbanization has likewise been dominated by single-person households, flat-sharing adults, and young parents (Buzar et al. 2007). The importance of young adults to this process, at least in Europe, is confirmed by Kabisch and Haase (2011), who find that younger, smaller households are a key driver of reurbanization across the whole continent.

An emerging body of literature, particularly that of Moos, has explicitly considered the location patterns of young adults. Moos (2014b) models the location patterns of young adults in Montreal and Vancouver, in both 1981 and 2006. While household characteristics, such as size, remain the most important determinants of residential location, young adults are increasingly associated with density over time, as well as to rapid transit in Vancouver, after controlling for other factors associated with residential location decisions. However, the models also identify an association between young adult populations and distance from the centre, implying that the 
centralized pattern is at least in part a result of demographic characteristics constraining choices rather than a preference for central living. Moos (2014b) argues that the presence of urban amenities and smaller dwelling units in central neighbourhoods draws young adults to these places, while the high costs of living in these areas push them away, tending toward "decentralized concentration" rather than centralization, especially in Vancouver, where housing prices are higher.

In a separate paper, Moos (2015) models urban density as a function of census tract characteristics, including age, household size, household income, the share of immigrants, and the share of potential gentrifiers (as identified by their employment in the quaternary sector of the economy), for both 1981 and 2006 in Montreal, Toronto, and Vancouver. ${ }^{3}$ Considering density an indicator of urbanity, Moos (2015) finds that the presence of young adults became an increasingly strong predictor of urban living over the period of study, although it bears noting that the share of immigrants remained more closely associated with density. At the same time, the significance of age, distinct from that of the share of potential gentrifiers or of income, suggests a separate - although not necessarily mutually exclusive - process, which Moos terms "youthification."

However, as van Criekingen $(2010,384)$ argues, largely in response to the reurbanization literature (e.g., Buzar, Hall, and Ogden 2007; Buzar et al. 2007) - but no less pertinently here - it is important not to "inappropriately [bring] the social class dimension out of the discussion of urban change." Indeed, as Moos (2015) himself notes, youthification appears to be common in areas that are both already gentrified, and that already contained relatively high shares of young adults (see also Moos 2014b). Van Criekingen (2010) also empirically demonstrates that young adults living in central Brussels are generally educated, mobile white- 
collar workers. As they are predominantly renters, they have contributed to gentrification by pushing up rents, displacing or further impoverishing low-income groups that traditionally comprise renters in the inner area. This example illustrates concretely that diverse housing pathways are entangled, as some young adults' experiences may exclude others from particular urban spaces, and thereby confine them to a separate set of pathways.

Nevertheless, the concept of "forever young" neighbourhoods (Moos 2015) does seem to carry some weight. "Re-urbanizing" young adults in both Britain and continental Europe express intentions to move out of central neighbourhoods in the long term, often for what they perceive to be better neighbourhoods for raising children (Bromley, Tallon, and Roberts 2007; Buzar et al. 2007). This mobility is facilitated by the high share of these households in rental tenure (Bromley, Tallon, and Roberts 2007; van Criekingen, 2010). The young adults implicated in gentrification of Canadian cities were also characterized by a high level of residential mobility (Meligrana and Skaburskis 2005). It would seem that youthification (and gentrification) by young adults is tied to particular housing pathways associated with mobility and advantaged trajectories. Increasingly, university studenthood plays an important role in shaping these pathways.

\section{Studentification: Studenthood and the Neighbourhood}

University students, who largely but not exclusively represent a subgroup of young adults, also possess distinct geographies. Notably, these geographies are expressed through the process of "studentification," which "engenders the distinct social, cultural, economic and physical transformations within university towns, which are associated with the seasonal, inmigration of [higher education] students" (Smith 2005, 73), particularly within specific neighbourhoods. Academically, the subject is most widely documented in the United Kingdom, 
although it is evident across the Anglo-American world - as in Melbourne, Australia (Davison 2009; Fincher and Shaw 2009); Cork City, Ireland (Kenna 2011); Waterloo, Canada

(Charbonneau, Johnson, and Andrey 2006); Athens, Georgia, USA (Pickren 2012) - and elsewhere, such as in Ciudad Real, Spain (Garmendia, Coronado, and Ureña 2012); Kuala Lumpur, Malaysia (Sabri and Ludin 2009); and Guangzhou, China (He 2015).

Conventionally, studentification has been associated with the expansion of higher education and increasing numbers of students domestically (e.g., Smith 2009), while others have drawn attention to the importance of the increasing number of international students in driving the process in many English-speaking countries as a result of the "internationalisation of ‘Western' education systems” (Waters 2006, 1053; Fincher and Shaw 2009). He (2015) in particular has drawn attention to the role of institutional actors in shaping the geographical contingencies of studentification across international contexts, such that the form it takes may be considerably different in different places. Within the UK, such highly-concentrated student neighbourhoods are most common - and most segregated - in cities with higher proportions of students in the total urban population (Munro, Turok, and Livingston 2009). Studentification can proceed slowly, over decades, or quickly, within the span of a couple years (Sage, Smith, and Hubbard 2012), sometimes quietly, and at other times with vocal opposition from local nonstudent residents (Hubbard 2008).

Such opposition usually centres on the disruption of supposedly "balanced" neighbourhoods by students who are less-than-mindful of noise (e.g., from parties) or garbage pickup routines, the deterioration of the physical environment, the displacement of families and the resultant decline of local schools, pressure on parking due to the increase in houses in multiple occupation, and the pricing-out of other residents (Bromley 2006; Hubbard 2008; 
Munro and Livingston 2012; Smith and Holt 2007; Smith 2005). These disruptions have been the impetus for a variety of planning and policy interventions such as thresholds on the amount of student housing permitted within a neighbourhood (Hubbard 2008), limits on the number of unrelated occupants permitted in a single apartment (Bromley 2006; Pickren 2012), licensing procedures for landlords of housing in multiple occupation, regulating property conversions, and identifying sites to develop student housing that will have less impact on established neighbourhoods (Smith 2008). Many communities have also developed "town and gown" committees, including representatives from both the university and the community at large, to manage the impacts of institutions on the local area; these, however, usually extend beyond a narrow focus on studentification to incorporate a broader range of issues (Kemp 2013; Bromley 2006).

Scholars have also focused on studentification as a process of segregation and displacement. Student lifestyles are temporally (e.g. on weeknights rather than weekends) and spatially constructed (in particular parts of the city) (Chatterton 1999). However, these spaces can be sources of tension and conflict, and as traditional students are typically upper- or middleclass, they are best seen as producing exclusive geographies, rather than to be celebrated as exemplars of the "consumption-oriented postmodern city as a stage for the enactment of lifestyle" (Chatterton 1999, 132). Indeed, a common response to the issues posed by studentification is an increase in the amount of purpose-built student accommodation (PBSA). While this may serve to reduce the concentration and proliferation of students living in traditional neighbourhoods (Hubbard 2009) - although certainly not always, as it may in fact draw students to the neighbourhoods surrounding the PBSA (Sage, Smith, and Hubbard 2013) - 
the irony is that such a strategy simply reinforces the segregation of students from the rest of society (Smith and Hubbard 2014).

Furthermore, most of these developments take the form of exclusive "student villages" marketed to a particular view of the student lifestyle (Smith and Hubbard 2014), forming "de facto gated communities" (Hubbard 2009, 1920). Those excluded from these high-amenity, highrent PBSAs are not only non-students, but less affluent students as well (Smith and Hubbard 2014), lending support to the claim that student pathways are not homogenous. In some instances, studentification may even take the form of actual gated communities that actively displace working-class populations (Pickren 2012). Once again, we see how particular housing pathways - in this case, those of affluent students - collide with other pathways - those of lessaffluent students and the working class - and that these create tangible impacts on the urban environment.

In this way, studentification may be more akin than youthification to "classic" definitions of gentrification, although hopefully this review makes clear that these terms are inherently interrelated in complex ways. Indeed, Smith (2005) outlines the economic, social, cultural, and physical commonalities between studentification and gentrification. For instance, both processes entail revalorization and recommodification of housing, displacement by a generally middleclass population, shared cultural practices of incomers, and physical alterations to properties. The university is thus posited as a "gentrification factory" which grants students access to professional status, with life in studentified neighbourhoods contributing to the development of middle-class cultural practices likely to carry into future housing choices (Smith 2005, 86; Smith and Holt 2007; Sage, Smith, and Hubbard 2013). As Sage, Smith, and Hubbard (2013) observe, through the expansion of higher education and the growth of PBSA, studentification is 
increasingly important in shaping the potential housing pathways of a larger proportion of the population, as it creates certain cultural preferences regarding the choice to live on or off campus, and as young adults live in age- and class-segregated environments that may cultivate preferences for such environments in future residential decisions. In the Australian context, early gentrification was in fact shaped by prior studentification associated with the expansion of higher education (Davison 2009). More directly, universities may actively engage in gentrification of nearby neighbourhoods under class-based and racialized discourses of improvement, in the name of student safety and in an attempt to compete globally to attract and retain students through appealing streetscapes (Bose 2015). The enactment of certain pathways therefore can be seen to have exclusionary impacts on more disadvantaged pathways.

On the other hand, some have conceived of studentification in more ambivalent terms. It may be seen not as a process of privileged gentrification but as one of "spatial marginalisation" due to students' propensity for indebtedness, low current incomes, disconnect with local communities, and separation from "mainstream" cultural spaces (Hubbard 2008, 324; although Hubbard's later writing [2009; Smith and Hubbard 2014], emphasizes the exclusivity of studentified spaces). Perhaps most interestingly, Hubbard (2008) notes the parallels between exclusionary discourses some pre-existing residents have openly employed regarding studentification, and xenophobic and racist sentiments that would normally be considered inappropriate. However, the implicitly class-based reactions to studentification mean students are often exempted from the "near demonisation of young people" for behaviour that in other contexts has received a correspondingly punitive response, such as binge drinking or congregating in supposedly-threatening groups (Munro and Livingston 2012, 1688). 
Studentification, if we are to consider it a form of gentrification (Smith and Holt 2007), is nonetheless a process that upsets conventional definitions of gentrification. It may involve a physical downgrading of the built environment (after an initial upgrading to make housing suitable for multiple occupation) concurrent with socio-economic upgrading (Smith and Holt 2007) and a reversal of tenurial transformation back toward renting rather than owner-occupation (Smith 2005). Therefore, studentification might be considered similar to Rose's (1984) notion of the "marginal gentrifier," whereby despite contributing to the gentrification process, its actors are not fully integrated into the privileged middle class position. Student pathways might therefore be suitably seen as aligning with strategies to leverage social and cultural capital to access housing that would otherwise be unattainable (Hochstenbach and Boterman 2015) and to develop a sense of home and belonging in a largely institutional context (Holton and Riley 2016).

\section{Pathways Forward: Directions for Research}

A number of directions for further research emerge from this discussion. The first relates primarily to a need to further explore the connections between studentification, youthification, and gentrification. To begin, research is needed to substantiate the claim that studentification does indeed shape preferences that carry on to later housing choices (Smith 2005; Smith and Holt 2007; Sage, Smith, and Hubbard 2013), and to what degree. This would provide a greater understanding of the extent to which studentification is a driver of youthification and traditional forms of gentrification. Meanwhile, youthification - like gentrification - is likely to have both cultural and economic explanations in terms of both how young adults' identities are constructed and the constraints they face in labour and housing markets. Here, a pathways framework could provide a tool to consider both the individual meanings and choices associated with these processes as well as the structural forces constraining them. The studentification literature has 
begun to think through the overlaps with gentrification, as well as some points of divergence between the processes (Smith 2005). However, as the proliferation of PBSA makes clear (Smith and Hubbard 2014), there remains a need to refocus attention on the role of capital in the studentification process, and the continuities between studentification and broader discussions of new-build gentrification and the financialization of real estate (Davidson and Lees 2010; Aalbers 2008). Such a research program would provide a further account of how studentification, youthification, and gentrification play off or contradict each other.

Second, research is needed to explicitly examine the role of studentification, youthification, and gentrification in shaping individual housing pathways, and vice versa, at both a broader societal scale, and that of the individual. For instance, demographic transitions that produce more young, single-person households may - among other factors - drive youthification, while the concentration of young adults in smaller housing stock typical of the phenomenon may simultaneously discourage the formation of larger households. Furthermore, as young adults' differential access to homeownership increasingly contributes to a worsening of disparities in wealth and well-being (McKee 2012), there is a need to explore the potential divergence between young adults' housing pathways over time, and the implications for youthification and studentification. In particular, a greater understanding is required of how these processes place certain pathways in conflict with each other. For example, increased time spent in the rental sector by young adults places differing housing pathways in conflict as it increases the demand for rental housing, in turn pushing up rents, with negative implications for low income households (Ford, Rugg, and Burrows 2002; Clapham et al. 2014; van Criekingen 2010). Attention must also be given to the ways young adults' housing pathways interact with those of other age groups. Age segregation produced by youthification and studentification may 
contribute to ageism and reinforce prejudices while hindering socialization and healthy ageing (Valentine 2015; Hagestad and Uhlenberg 2006). Meanwhile, the burdens of high housing costs and/or weak labour market position impact other family members through the "ripple effect," as parents need to support their adult children, potentially diverting support from their own elderly parents (the young adults' grandparents) and affecting the relative well-being of each generation (Sage, Evandrou, and Falkingham 2013). This is in keeping with recent calls to reconceptualise residential mobility as relational practice (Coulter, van Ham, and Findlay 2015) and to incorporate the "from below" experiences of displacement and housing affordability struggles lacking from much of the gentrification (and related) literature (Slater 2011, 580).

Third, attention must be given to forms of difference among youth such as gender, race, and ethnicity (Young 1997, Valentine 2003). Indeed, while the concepts of youthification and studentification arose as a means of adding nuance to debates on gentrification by showing how age and student status themselves matter as a form of difference, these emerging literatures have done little to explore substantive differences between young adults. ${ }^{4}$ Likewise, the research on housing pathways reviewed here gives little attention to these forms of difference, despite the fact that a pathways framework is conceptually well adapted to account for meanings and experiences of housing deriving from gender, race, ethnicity, or other axes of differentiation, in addition to those of class or household type (Clapham 2002). Research should make use of this versatility of the pathways approach.

To summarize, a pathways approach could provide insight into the links between youthification, studentification, and gentrification; the interactions between these processes and individual pathways, as well as among individual pathways; and forms of difference that intersect with young adulthood within the youthification and studentification processes. In 
studying these issues, it may be valuable to engage with literature on the geographies of age, which focuses broadly on the meanings and politics of age and relationships between generations (Hopkins and Pain 2007; Vanderbeck 2007; Vanderbeck and Worth 2015). Taken together, these areas of research are crucial to a complete understanding of the residential geographies of young adults.

\section{Conclusion}

Broadly speaking, changes in demographic trends as well as high housing prices and precarious labour markets have combined to create unique challenges and circumstances for young adults in terms of housing outcomes. In response, young adults may engage in a variety of housing pathways, often depending on family support or social and cultural capital to access suitable housing, but also potentially subject to a certain degree of precarity. This typically entails greater reliance on the private rental sector. These diverse pathways are expressed in urban space, as young adults are increasingly found in denser, inner city areas, through a process of youthification that is distinct from but nonetheless linked to gentrification. Students, as a particular subgroup of young adults, also tend to cluster in particular neighbourhoods, producing their own geographies of segregation. These spatial patterns in turn shape young adults' housing pathways as they exclude certain households from particular spaces, thus constraining the pathways available to them.

Yet, the interconnections between gentrification, youthification, and studentification remain theoretically and empirically underdeveloped, as are the ways these processes simultaneously shape and are shaped by individual housing pathways. Greater understanding is also needed as to how difference, for instance in terms of race, ethnicity, and gender, figures into youthification and studentification. To get at these issues, research must address individual 
experience, relationships between individuals, and connections to broader urban and social processes. 


\section{$\underline{\text { Notes }}$}

1. In doing so, I zero in on age (and student status) as a particular form of social differentiation. Detailed discussion of intersecting forms of difference such as race, ethnicity, and gender among young adults is precluded by both space, and the emergent nature of the urban structure literature under review, which has not substantively dealt with these topics. I highlight this as one of several crucial avenues for further research later in this article.

2. In suggesting the metaphor of "belonging" be used alongside that of "transitions" in research on youth, Cuervo and Wyn $(2014,905)$ argue that the "metaphor of pathways positions young people as navigators who make personal choices to invest in education, valorising the structures and relationships that create failure and inequality. What this approach leaves out of the picture is the overlapping structures and sets of relationships which create meaning for young people and that play a crucial role in their decisionmaking about education and work." This use of the term pathways, drawn from policies in the UK and Australia, is not the same as that elaborated by Clapham (2002) and adopted in this paper, which is very much concerned with both structures and meanings.

3. Location quotient maps of all 57 metropolitan areas in the US and Canada with population over 1 million suggest some generalizability beyond these three cities (see Generationed City n.d.).

4. A notable exception is an account of studentification in Melbourne leading to the segregation of foreign students (Fincher and Shaw 2009). 


\section{Acknowledgments}

This work was supported by an Ontario Graduate Scholarship. Markus Moos provided comments on an earlier draft, and Editor Barney Warf and an anonymous reviewer suggested useful improvements to this work. This article also benefitted from conversations with Beth Davies, Jennifer Dean, Margaret Ellis-Young, and Nancy Worth. Responsibility for this work, however, remains my own. 


\section{$\underline{\text { References }}$}

Aalbers, M. B. 2008. The Financialization of Home and the Mortgage Market Crisis. Competition \& Change 12 (2): 148-166.

Arnold, D. and Bongiovi, J. R. 2013. Precarious, Informalizing, and Flexible Work: Transforming Concepts and Understandings. American Behavioural Scientist 57 (3): 289308.

Arundel, R. and Ronald, R. 2016. Parental co-residence, shared living and emerging adulthood in Europe: semi-dependent housing across welfare regime and housing system context. Journal of Youth Studies 19 (7): 885-905.

Beer, A. and Faulkner, D. with Paris, C. and Clower, T. 2011. Housing transitions through the life course: Aspirations, needs and policy. Portland, OR: Policy Press.

Bose, S. 2015. Universities and the redevelopment politics of the neoliberal city. Urban Studies 52 (14): 2616-2632.

Bromley, R. 2006. On and Off Campus: Colleges and Universities as Local Stakeholders. Planning, Practice \& Research 21 (1): 1-24.

Bromley, R. D. F., Tallon, A. R., and Roberts, A. J. 2007. New populations in the British city centre: Evidence of social change from the census and household surveys. Geoforum 38: 138-154.

Brown, W. M. and Lafrance, A. 2013. Trends in Homeownership by Age and Household Income: Factors Associated with the Decision to Own, 1981-2006. Economic Analysis Research Paper Series no. 83. Statistics Canada Catalogue no. 11F0027M. Ottawa, ON: Minister of Industry. 
Buzar, S., Hall, R., and Ogden, P. E. 2007. Beyond gentrification: the demographic reurbanisation of Bologna. Environment and Planning A 39: 64-85.

Buzar, S., Ogden, P., Hall, R., Haase, A., Kabisch, S., and Steinführer, A. 2007. Splintering Urban Populations: Emergent Landscapes of Reurbanisation in Four European Cities. Urban Studies 44 (4): 651-677.

Charbonneau, P., Johnson, L.C., and Andrey, J. 2006. Characteristics of University Student Housing and Implications for Urban Development in Mid-sized Cities. Canadian Journal of Urban Research 15 (2): 278-300.

Chatterton, P. 1999. University students and city centres - the formation of exclusive geographies: The case of Bristol, UK. Geoforum 30: 117-133.

Clapham, D. 2002. Housing Pathways: A Post Modern Analytical Framework. Housing, Theory and Society 19 (2): 57-68.

Clapham, D., Mackie, P., Orford, S., Thomas, I., and Buckley, K. 2014. The housing pathways of young people in the UK. Environment and Planning A 46: 2016-2031.

Clark, W. 2007. Delayed transitions of young adults. Canadian Social Trends 84: 13-21. Statistics Canada Catalogue no. 11-008.

Côté, J. and Bynner, J. M. 2008. Changes in the transition to adulthood in the UK and Canada: the role of structure and agency in emerging adulthood. Journal of Youth Studies 11 (3): 251-268.

Coulter, R., van Ham, M., and Findlay, A. M. 2015. Re-thinking residential mobility: Linking lives through time and space. Progress in Human Geography. DOI: $10.1177 / 0309132515575417$ 
Cuervo, H. and Wyn, J. 2014. Reflections on the use of spatial and relational metaphors in youth studies. Journal of Youth Studies 17 (7): 901-915.

Davidson, M. and Lees, L. 2010. New-Build Gentrification: Its Histories, Trajectories, and Critical Geographies. Population, Space and Place 16: 395-411.

Davison, G. 2009. Carlton and the Campus: The University and the Gentrification of Inner Melbourne 1958 - 75. Urban Policy and Research 27 (3): 253-264.

Demographia. 2015. 11th Annual Demographia International Housing Affordability Survey. Retrieved December 7, 2015 from http://www.demographia.com/dhi.pdf

Emmanuel, D. 2013. Balancing autonomy, status and family in the transition to adulthood: class and housing aspects of the Southern European model in Athens, 1987-2004. In Young People and Housing: Transitions, Trajectories and Generational Fractures, ed. R. Forrest and N. M. Yip, 19-41. New York: Routledge.

Evans, B. 2008. Geographies of Youth/Young People. Geography Compass 2 (5): 1659-1680.

Fincher, R. and Shaw, K. 2009. The unintended segregation of transnational students in central Melbourne. Environment and Planning A 41: 1884-1902.

Ford, J., Rugg, J. and Burrows, R. 2002. Conceptualising the Contemporary Role of Housing in the Transition to Adult Life in England. Urban Studies 39 (13): 2455-2467.

Furlong, A. and Cartmel, F. 2007. Young People and Social Change: New Perspectives ( $2^{\text {nd }}$ ed). Bristol, PA: Open University Press.

Garmendia, M., Coronado, J. M., and Ureña, J. M. 2012. University Students Sharing Flats: When Studentification Becomes Vertical. Urban Studies 49 (12): 2651-2668.

Generationed City. n.d. Where do young adults live? Retrieved December 7, 2015 from http://generationedcity.uwaterloo.ca/2014/10/16/where-do-young-adults-live/ 
Gorman-Murray, A. 2015. Twentysomethings and twentagers: subjectivities, spaces and young men and home. Gender, Place and Culture 22 (3): 422-439.

Haartsen, T. and Thissen, F. 2014. The success-failure dichotomy revisited: young adults' motives to return to their rural home region. Children's Geographies 12 (1): 87-101.

Hagestad, G. O. and Uhlenberg, P. 2006. Should We Be Concerned About Age Segregation? Some Theoretical and Empirical Explorations. Research on Aging 28 (6): 638-653.

Hall, T., Coffey, A. and Lashua B. 2009. Steps and stages: rethinking transitions in youth and place. Journal of Youth Studies 12 (5): 547-561.

He, S. 2015. Consuming urban living in 'villages in the city': Studentification in Guangzhou, China. Urban Studies 52 (15): 2849-2873.

Heath, S. and Calvert, E. 2013. Gifts, Loans, and Intergenerational Support for Young Adults. Sociology 47 (6): 1120-1135.

Hochstenbach, C. and Boterman, W. R. 2015. Navigating the field of housing: housing pathways of young people in Amsterdam. Journal of Housing and the Built Environment 30: 257274.

Holton, M. and Riley, M. 2016. Student geographies and homemaking: personal belonging(s) and identities. Social \& Cultural Geography 17 (5): 623-645.

Hoolachan, J., McKee, K., Moore, T. and Soaita, A. M. 2016. 'Generation rent' and the ability to 'settle down': economic and geographic variation in young people's housing transitions. Journal of Youth Studies. DOI: 10.1080/13676261.2016.1184241

Hopkins, P. and Pain, R. 2007. Geographies of age: thinking relationally. Area 39 (3): 287-294. Hörschelmann, K. and van Blerk, L. 2012. Children, Youth and the City. New York: Routledge. 
Hubbard, P. 2008. Regulating the social impacts of studentification: a Loughborough case study. Environment and Planning A 40: 323-341.

Hubbard, P. 2009. Geographies of studentification and purpose-built student accommodation: leading separate lives? Environment and Planning A 41: 1903-1923.

Kabisch, N. and Haase, D. 2011. Diversifying European Agglomerations: Evidence of Urban Population Trends for the $21^{\text {st }}$ Century. Population, Space and Place 17: 236-253.

Kemp, R. L. (ed.) 2013. Town and Gown Relations: A Handbook of Best Practices. Jefferson, NC: McFarland and Company.

Kenna, T. 2011. Studentification in Ireland? Analysing the impacts of students and student accommodation on Cork City. Irish Geography 44 (2-3): 191-213.

Li, W. D. H. 2013. The living arrangements of just-married young adults in Taiwan. In Young People and Housing: Transitions, Trajectories and Generational Fractures, ed. R. Forrest and N. M. Yip, 89-104. New York: Routledge.

McKee, K. 2012. Young People, Homeownership and Future Welfare. Housing Studies 27 (6): 853-862.

Meligrana, J. and Skaburskis, A. 2005. Extent, Location and Profiles of Continuing Gentrification in Canadian Metropolitan Areas, 1981-2001. Urban Studies 42 (9): 15691592.

Mendez, P. 2011. Ambiguity at home: unauthorized geographies of housing in Vancouver. Unpublished PhD dissertation, University of British Columbia. Retrieved March 19, 2015 from https://circle.ubc.ca/handle/2429/39746

Moos, M. 2014a. Generational Dimensions of Neoliberal and Post-Fordist Restructuring: The Changing Characteristics of Young Adults and Growing Income Inequality in Montreal 
and Vancouver. International Journal of Urban and Regional Research 38 (6): 20782102.

Moos, M. 2014b. “Generationed” space: Societal restructuring and young adults' changing residential location patterns. The Canadian Geographer 58 (1): 11-33.

Moos, M. 2015. From gentrification to youthification? The increasing importance of young age in delineating high-density living. Urban Studies. DOI: 10.1177/0042098015603292

Munro, M. and Livingston, M. 2012. Student Impacts on Urban Neighbourhoods: Policy Approaches, Discourses and Dilemmas. Urban Studies 49 (8): 1679-1694.

Munro, M., Turok, I., and Livingston, M. 2009. Students in cities: a preliminary analysis of their patterns and effects. Environment and Planning A 41: 1805-1825.

Öst, C. E. 2012a. Housing and children: simultaneous decisions? - a cohort study of young adults' housing and family formation decision. Journal of Population Economics 25: 349-366.

Öst, C. E. 2012b. Parental Wealth and First-time Homeownership: A Cohort Study of Family Background and Young Adults' Housing Situation in Sweden. Urban Studies 49 (10): $2137-2152$.

Pickren, G. 2012. "Where Can I Build My Student Housing?" The Politics of Studentification in Athens-Clarke County, Georgia. Southeastern Geographer 52 (2): 113-130.

Poggio, T. 2013. The first steps into the Italian housing system: inequality between generational gaps and intergenerational transfers. In Young People and Housing: Transitions, Trajectories and Generational Fractures, ed. R. Forrest and N. M. Yip, 42-63. New York: Routledge. 
Rérat, P. 2014. Highly qualified rural youth: why do young graduates return to their home region? Children's Geographies 12 (1): 70-86.

Rose, D. 1984. Rethinking gentrification: Beyond the uneven development of Marxist urban theory. Environment and Planning D: Society and Space 2 (1): 47-74.

Rosenberg, M. W. and Wilson, D. H. 2010. Younger Cities, Older Cities, and Cities in the Balance: Spaces and Places of the Younger and Older Population. In Canadian Cities in Transition (4th ed.), ed. T. Bunting, P. Filion, and R. Walker, 357-374. Don Mills, ON: Oxford University Press.

Sabri, S. and Ludin, A. N. M. (2009). "Studentification": Is it a key factor within the residential decision-making process in Kuala Lumpur? In: South East Asian Technical Universities Consortium (SEATUC) - 3rd SEATUC Symposium Proceeding, 25th - 26th February 2009, Johor Bahru, Malaysia. Retrieved December 2, 2015 from http://eprints.utm.my/12452/

Sage, J., Evandrou, M., and Falkingham, J. 2013. Onwards or Homewards? Complex Graduate Migration Pathways, Well-being, and the 'Parental Safety Net'. Population, Space and Place 19: 738-755.

Sage, J., Smith, D., and Hubbard, P. 2012. The Rapidity of Studentification and Population Change: There Goes the (Student)hood. Population, Space and Place 18: 597-613.

Sage, J., Smith, D., and Hubbard, P. 2013. New-build Studentification: A Panacea for Balanced Communities? Urban Studies 50 (13): 2623-2641.

Sager, T. 2011. Neo-liberal urban planning policies: A literature survey 1990-2010. Progress in Planning 76: 147-199. 
Slater, T. 2011. Gentrification of the City. In The New Blackwell Companion to the City, ed. G. Bridge and S. Watson, 571-585. Malden, MA: Wiley-Blackwell.

Smith, D. P. 2005. 'Studentification': the gentrification factory? In Gentrification in a Global Context: The new urban colonialism, ed. R. Atkinson and G. Bridge, 72-89. New York: Routledge.

Smith, D. 2008. The Politics of Studentification and '(Un)balanced' Urban Populations: Lessons for Gentrification and Sustainable Communities? Urban Studies 45 (12): 2541-2564.

Smith, D. 2009. Guest editorial. Environment and Planning A 41: 1795-1804.

Smith, D. P. \& Holt, L. 2007. Studentification and “apprentice" gentrifiers within Britain's provincial towns and cities: extending the meaning of gentrification. Environment and Planning A 39: 142-161.

Smith, D. P. and Hubbard, P. 2014. The segregation of educated youth and dynamic geographies of studentification. Area 46 (1): 92-100.

Townshend, I. \& Walker, R. 2015. Life Course and Lifestyle Changes: Urban Change Through the Lens of Demography. In Canadian Cities in Transition: Perspectives for an Urban Age $\left(5^{\text {th }}\right.$ ed.), ed. P. Filion, M. Moos, T. Vinodrai, and R. Walker, 109-128. Don Mills, ON: Oxford University Press.

Valentine, G. 2003. Boundary Crossings: Transitions from Childhood to Adulthood. Children's Geographies 1 (1): 37-52.

Valentine, G. 2015. Intergenerationality and prejudice. In Intergenerational Space, ed. R. M. Vanderbeck and N. Worth, 155-168. New York: Routledge. 
Van Criekingen, M. 2010. 'Gentrifying the Re-urbanisation Debate', Not Vice Versa: The Uneven Socio-spatial Implications of Changing Transitions to Adulthood in Brussels. Population, Space and Place 16: 381-394.

Vanderbeck, R. M. 2007. Intergenerational Geographies: Age Relations, Segregation and Reengagements. Geography Compass 1 (2): 200-221.

Vanderbeck, R. M. and Worth, N. (eds.) 2015. Intergenerational Space. New York: Routledge.

Vosko, L. F. (ed.) 2006. Precarious Employment: Understanding Labour Market Insecurity in Canada. Kingston, ON and Montreal, QC: McGill-Queens University Press.

Walks, A. 2013. Mapping the urban debtscape: The geography of household debt in Canadian cities. Urban Geography 34 (2): 153-187.

Walks, A. 2014. Canada's Housing Bubble Story: Mortgage Securitization, the State, and the Global Financial Crisis. International Journal of Urban and Regional Research 38 (1): 256-284.

Waters, J. L. 2006. Emergent Geographies of International Education and Social Exclusion. Antipode 38 (5): 1046-1068.

Yip, N. M. 2013. Homeownership, cohort trajectories and Hong Kong's post-eighties generation. In Young People and Housing: Transitions, Trajectories and Generational Fractures, ed. R. Forrest and N. M. Yip, 122-140. New York: Routledge.

Young, I. M. 1997. Intersecting Voices: Dilemmas of gender, political philosophy, and policy. Princeton, NJ: Princeton University Press.

Zavisca, J. 2013. The lived experience of housing among young people in Russia. In Young People and Housing: Transitions, Trajectories and Generational Fractures, ed. R. Forrest and N. M. Yip, 217-234. New York: Routledge. 
NICK REVINGTON is a PhD student in the School of Planning at the University of Waterloo, Waterloo, ON, Canada N2L 3G1. E-mail: nwreving@uwaterloo.ca. His research interests include housing, urban change, and the role of capital therein, with a current focus on socalled "college towns." 